\title{
Inter- and Intra-Theatre Learning and British Coastal Air Power in the Second
}

\section{World War}

\section{I: Introduction}

The Second World War was truly global in scale. Britain, like most of the main combatant nations, was forced to respond to the transformation of what had been a geographically contained war into one in which they fought in diverse theatres across three continents, all of the world's oceans and many of its seas. Doing this required the armed forces to learn, develop and adapt to new situations, environments, techniques, technologies and dynamic enemies in order to be operationally effective. Yet so far, historians have not fully integrated studies of learning with the global nature of the war. There is little mention of the influence of developments undertaken in different theatres on each other, or interrogation as to whether there was deliberate cross-fertilisation between them. This shortcoming stands in stark contrast to the historiography of learning in the First World War, where the literature has progressed into a more nuanced state, most recently including research into the role of intertheatre learning within the development of the British Army. ${ }^{1}$

Few historians of Britain's armed forces in the Second World War have attempted to assess the importance of inter-theatre links to the process and outcome of learning. ${ }^{2}$ Some have denied its very existence. Williamson Murray, for example, is extremely critical, claiming deliberate ignorance by the British:

\footnotetext{
${ }^{1}$ For an assessment of the progression of learning in the historiography of the British and German Armies in the First World War, see R. Foley, 'Dumb Donkeys or Cunning Foxes? Learning in the British and German Armies during the Great War', International Affairs, 90, 2 (2014), pp. 279-82. On inter-theatre aspects, see A. Fox-Godden, 'Beyond the Western Front: The Practice of Inter-Theatre Learning in the British Army during the First World War', War in History, 23, 2 (2016), pp. 190-209.

2 For an exception, see Tim Moreman, The Jungle, Japanese and the British Commonwealth Armies at War 1941 1945: Fighting Methods, Doctrine and Training for Jungle Warfare (London, 2005). Moreman has shown that developments in Jungle warfare by the Australians in the Pacifictheatre were passed onto Slim's army in Burma via assigned liais on officers and later a full military mission, which were of use over 1943-45.
} 
'There was ample information flowing back from the Middle East theatre, but the Home Forces appear to have paid virtually no attention to such after-action reports. Each division working up for combat for the first time had to innovate al most entirely on its own. Hence tactical innovation came on the battlefield - a most expensive school.' ${ }^{3}$ David French's more refined analysis claims that 'The experience of defeat in France, Greece and North Africa taught the British to avoid operational manoeuvre in favour of set-piece of attrition battles based on the possession of superior quantities of material. ${ }^{4}$ This suggests an ability to learn from recent experience, but not to transfer knowledge between theatres while engagements were concurrent. This article establishes that the British were in fact capable of dynamic inter-theatre learning, by analysing their development of coastal air power. ${ }^{5}$ It offers a first step towards addressing the lack of studies that integrate learning with the global nature of the war, by demonstrating the significant influence of inter-theatre links in the development of this crucial capability.

Success in the maritime environment was utterly essential to British survival, and later Allied victory, in the Second World War. As historians who have tried to explain the outcome of the war have recognised, air power was a fundamental ingredient in this success, and for Britain coastal air power played a particularly important role. ${ }^{6}$ Britain was dependent on keeping vital sea communications open in order to avoid starvation, maintain its war effort, and later to import military forces from America. Offensively, success at sea meant strangling the enemy's own communications, and the neutralisation of the German Navy. As the war expanded in scope, new theatres were opened to be contested; the Mediterranean in June 1940, and the Indian Ocean in December $1941 .^{7}$ In each, communications had to be protected to ferry men

\footnotetext{
${ }^{3}$ W. Murray, 'British Military Effectiveness in the Second World War' in A. Mill et and W. Murray eds. Military Effectiveness, vol. 3 (Cambridge, 2010), p. 98.

${ }^{4}$ D. French, Raising Churchill's Army: The British Army and the War against Germany, 1919-1945 (Oxford, 2001$)$, p. 246.

5 This article treats British coastal air power as all aircraft operating over the sea from land, incorporating both Royal Air Force (RAF) and Fleet Air Arm (FAA) machines.

${ }^{6}$ See for example R. Overy, Why the Allies Won (London, 1996), pp. 25-62 and P.P. O'Brien, How the War was Won: Air-Sea Power and Allied Victory in World War II (Cambridge, 2015), pp. 3, 184-5, 232.

7 The Japanese entry to the war opened both the Indian and Pacific oceans as maritime theatres, but British coastal air power only played a substantial role in the former.
} 
and materiel to and from important outposts and distant fronts. Coastal air power was integral in interdicting Axis communications across the Mediterranean, as well as providing other vital services. ${ }^{8}$ Further East it played a more limited role against Japanese sea communications with Burma, but there is some evidence of effect on Japanese logistics. ${ }^{9}$

In spite of the later results achieved through coastal air power, a well-developed historiography convincingly demonstrates that Britain entered the war in a gravely unprepared position in terms of resource allocation, training, doctrine and equipment. ${ }^{10}$ The dire situation was transformed by a combination of investment and substantial learning and development, which ultimately delivered operationally effective air power at sea. The existing literature offers some insight into this process, but remains theatre-specific and rarely comparative. Learning within RAF Coastal Command has received substantial treatment, incorporating the genesis and adoption of new structures, techniques and technologies. ${ }^{11}$ Overall, it demonstrates that the learning and development that was undertaken was broadly successful in adapting a highly

\footnotetext{
8 See R. S. Ehlers, The Mediterranean Air War: Air Power and Allied Victory in World War II (Lawrence, 2015); Hammond, 'British Aero-Naval co-operation in the Mediterranean, 1940-45, and the Creation of RAF No. 201 (Naval Co-operation) Group' in M. LoCicero, R. Mahoney and S. Mitchell, ed., A Military Transformed? Adaptation and Innovation in the British Military, 1792-1945 (Solihull, 2014), p. 233; R. Hammond, 'Air Power and the British Anti-Shipping Campaign in the Mediterranean, 1940-1944', Air Power Review, 16, 1 (2013), pp. 50-69; D. Austin, Malta and British Strategic Policy, 1925-1943 (London, 2004).

9 'Air Chi ef Marshal Sir Keith Park's Despatch on Air Operations in South East Asia from 1 June 1944 to the Occupation of Rangoon, 2 May 1945' in J. Grehan and M. Mace (eds), Despatches from the front: Far East Air Operations, 1942-1945 (Barnsley, 2014), pp. 122, 126-7; H. Probert, The Forgotten Air Force: The Royal Air Force and the War Against Japan, 1919-1945 (London, 1995), p. 143.

${ }^{10}$ Key texts on coastal air power in the interwar period include G. Till, Air Power and the Royal Navy, 1914-1945: A Historical Perspective (London, 1979); Buckley, The RAF and Trade Defence, ch. 1-4; C. Goulter, Forgotten Offensive: Royal Air Force Coastal Command's Anti-Shipping Campaign, 1940-1945 (Abingdon, 1995), ch. 2-3; P. Weir, 'The Development of Naval Air Warfare by the Royal Navy and Fleet Air Arm between the two World Wars' (PhD, University of Exeter, 2007); J. Levy, 'The Development of British Naval Aviation: Preparing the Fleet Air Arm for War, 1934-1939', Global War Studies, 9, 2 (2012), pp. 6-38; A. Cumming, The Battle for Britain: Inter-service Rivalry between the Royal Air Force and Royal Navy, 1909-1940 (Annapolis, 2015); D. Gates and B. Jones, Air Power in the Maritime Environment: The World Wars (Abingdon, 2016).

${ }_{11}$ Air Historical Branch (AHB) unpublished narrative, The RAF and Maritime War - volumes I-V deal with the Atlantic and Home waters; J. Buckley, The RAF and Trade Defence, 1919-1945: Constant Endeavour (Keele, 1995); A. Hendrie, The Cinderella Service: RAF Coastal Command, 1939-1945 (Barnsley, 2006); Goulter, Forgotten Offensive; R. Nesbit, The Strike Wings: Special Anti-Shipping Squadrons, 1942-45 (London, 1995); A. Price, Aircraft versus Submarine: The Evolution of Anti-Submarine Aircraft, 1912-1945 (London, 1973); C.H. Waddington, O.R. in World War II: Operational Research against the U-boat (London, 1973); R. Goette, 'The British Joint Area Combined Headquarters Scheme and the Command and Control of Maritime Air Power', Air Power Review, 14, 3 (2011), pp. 119-135.
} 
under-prepared organisation into an operationally effective one. Research on overseas theatres is less extensive but a notable corpus on the Mediterranean highlights the existence of learning in various roles. ${ }^{12}$ Work is limited on the Indian Ocean, which saw less intensive involvement than the other theatres in terms of scale of effort and perceived importance, but the slow pace at which learning occurred has been identified. ${ }^{13}$

The consequent depiction of learning and development is that it was distinctly compartmentalized within each theatre. This has led to an impression that it was not cultivated between and across theatres, while the difficult but broadly successful process of its conduct and dissemination has also been under-represented. ${ }^{14}$ Using under and un-utilised source material, including conference minutes, after-action reports, unit publications and private papers of relevant senior officers and scientists, this article demonstrates that while much of the learning and development took place intra-theatre, there was a strong current of intertheatre learning as well. This was delivered via a mixed methodology that incorporated informal means, such as the transfer of people and the use of informal knowledge networks, and more formalised routes like scientific research and the creation of doctrine. Links were particularly strong between the Home theatre and the Mediterranean, where a cyclical, mutually beneficial relationship was created. This increasingly comprehensive connection helped drive improvements that were ultimately highly important towards final success in each, and in the war as a whole. For the Indian Ocean, however, the transfer of knowledge was firmly one-way. It received, rather belatedly, experienced personnel, new technologies and direction on techniques and procedures that improved efficiency greatly, but could offer nothing in return, thanks primarily to consistently low priority and investment.

\footnotetext{
12 AHB, The RAF and Maritime War, vols.6-7; Ehlers, Mediterranean Air War; Nesbit, The Armed Rovers: Beauforts and Beaufighters over the Mediterranean (Shrewsbury, 1995); Hammond, 'Anti-Shipping Campaign'; Hammond, 'Aero-Naval Co-operation'; M. Simpson, 'Wings over the Sea: The Interaction of Air and Sea Power in the Mediterranean, 1940-1942' in Rodger, ed., Naval Power in the Twentieth Century (Basingstoke, 1996).

13 AHB, The RAF and Maritime War, vol. 7 part 3; Probert, Forgotten Air Force; A. Banks, Wings of the Dawning: The Battle for the Indian Ocean, 1939-1945 (Malvern, 1996).

14 The issue of the dissemination process in general is dealt with quite rarely in the literature on air power in the Second World War, but for a recent exception, which does not relate to coastal air power, see N.A Kollers, R. Muller and A. Santora, 'Learning to Fight and Fighting to Learn: Practitioners and the Role of Unit Publications in VIII Fighter Command, 1943-1944', Journal of Strategic Studies, published online 29 August 2016.
} 


\section{II: Coastal Command and an Intra-Theatre Learning Process}

Coastal Command started the war with ad-hoc, haphazard methods for intra-theatre learning, but soon became more sophisticated and formalized. Reports, assessments and the results of interviews with aircrew were shared in an increasingly systematic manner to ensure they reached the relevant authorities. New organizations were founded in order to conduct research into the collected data, make recommendations and conduct trials of new weapons, equipment and techniques. New tactical procedures and information on the use of new equipment was then disseminated back to units in an increasingly thorough manner, assisted by the use of publications, to help ensure promulgation to all ranks and personnel. While this increasingly formalized process generally followed a progressive path of improvement, it was not always a linear one, nor did it completely halt localized learning and adaptation by individual units. It did, however, establish a solid foundation for more systematized knowledge exchange between theatres; a fundamental change from Coastal Command's state at the outset of the war.

The interwar years had been characterised by a series of bitter disputes over which service should 'own' air power in the maritime environment, whether operating from land or warships. These disputes often left it directionless, with little development. The RAF instead spent the interwar years concentrating primarily on the evolution of strategic bombing and fighter defence, and the Navy largely on traditional fleet operations. ${ }^{15}$ One stark indicator of the impact of this neglect on coastal development can be seen in the 1928 production of the first RAF War Manual (Operations). The entire content of the chapter entitled 'Aircraft in Cooperation with the Navy' simply read 'In course of preparation'. This was not rectified until the publication of the second edition in February 1940, a full six months after the declaration of war with Germany. The one exception was in the area of Command and Control, where Area Combined Headquarters were created in 1938 to allow co-location of RAF Group Commanders with the Admiral for each major home Naval Command, and their respective staffs. This had

15 Goette, 'Command and Control', pp. 121-2. 
successfully facilitated closer co-ordination in pre-war exercises than earlier in the interwar years and would later become the model for operations overseas. ${ }^{16}$ Coastal Command was further hampered from concentrating its limited resources by indecision over what its primary role should be. The Admiralty, Air Ministry and its own Air Officer Commanding-in-Chief (AOCin-C) vacillated between reconnaissance, trade defence, fleet protection, strike force and even a reserve force for Fighter and Bomber Commands. It was belatedly settled in June 1939 as reconnaissance into the North Sea, although this was changed in December, for the final time, to trade defence. ${ }^{17}$

The North Sea reconnaissance requirements engaged the majority of the Command's limited capacity in 1939. Without modern aircraft, navigation equipment or any significant conceptual basis for operations, they began with only an unsophisticated procedure for simple 'line' patrols. These followed basic parallel tracks out to a set range and achieved little, despite over 9,300 flying hours from September to December 1939. They were later abandoned in favour of 'line and box' patrols that encompassed a wider area in a more efficient use of flying hours. By 1942 there were a variety of different reconnaissance techniques in use, specialized for the area and type of operation. This represented one of the first examples of intra-theatre learning, as squadron reports were passed on an ad-hoc basis back to headquarters, and the need for new techniques was determined. ${ }^{18}$

Similar ad-hoc methods were used to highlight problems in aircraft, equipment and weaponry. One important development was the replacement of the anti-submarine bomb with the aerial depth charge as the primary anti-submarine weapon. The former quickly proved to have an explosive charge that was completely inadequate to sink a U-boat, while fusing problems meant they often detonated at a sub-optimal moment. Indeed, its first wartime use actually brought

\footnotetext{
${ }^{16}$ See Joint Services Command and Staff College Archive (JSCSC), Air Publication 1300, Royal Air Force War Manual (Operations), July 1928, ch. 11; Air Publication 1300, Royal Air Force War Manual (Operations), second edition, February 1940, ch. 10.

${ }_{17}$ AHB, The RAF and Maritime War, Vol. 1: The Prelude, 1918-1939, pp. 225-9, 302, 323, 345-8.

${ }^{18}$ AHB, The RAF and Maritime War, Vol 1: The Prelude, 1918-1939, pp. 345-7 describes the patrol technique, while Map 3 shows an image of the patrol lines; Bowhill, 'Despatch', p. 15-6; Joubert de la Ferte, 'Despatch', p. 104.
} 
down the attacking aircraft rather than damaging the target! ${ }^{19}$ Complaints and anecdotal evidence were fed back to the AOC-in-C, Frederick Bowhill, not via any specific Coastal Command process but actually from the Navy's Vice Admiral (Submarines), Max Horton. Bowhill was able to pass this information on to the Torpedo and Mining Establishment to expedite aerial depth charge development. This started to be introduced to units in the summer of 1940 and quickly proved to be significantly more lethal to U-boats. ${ }^{20}$ Besides weaponry, problems with technical developments in radio location and general issues relating to anti-submarine warfare (ASW) at night also abounded. The first version of Air to Surface Vessel Radar (ASV) was given a limited distribution in January 1940, but experience quickly demonstrated it had significant problems, particularly when used at sea. Evidently improved versions were required, especially after the Fall of France gave German U-boats far greater access to the Atlantic and beyond. $^{21}$

From late 1940, new and more formalized methods of research and dissemination began to appear, including a more comprehensive scientific element. The Coastal Command Development Unit (CCDU) was created in November 1940 to represent the Command in a joint examination of the need for improved ASV, and to conduct trials of units in a maritime environment and advise on its best use. ${ }^{22}$ Meanwhile Patrick Blackett, an esteemed physicist and pioneer of operational research, was assigned to them as scientific advisor in March 1941, before becoming head of the newly created Operational Research Section (ORS) in June. It came to work in a closely intertwined manner with CCDU, with many of its theories and developments receiving operational testing and conceptual foundations through the latter. ${ }^{23}$

\footnotetext{
19 Milner, Atlantic, p. 20

20 TNA AIR 15/29, Horton to Bowhill, 22 July 1940; 'Despatch by Bowhill ' in Despatches, p. 30.

${ }^{21}$ Terraine, Right of the Line, pp. 239-40. Priority for the distribution of these sets, as with most of the latest equipment, went to Bomber Command.

22 JSCSC, Coastal Command Review, Vol. 3, No. 5, May 1944, pp. 22-23. It was later renamed the Air-Sea Warfare Development Unit.

${ }^{23}$ Air Publication 3368, Operational Research in the RAF (London, 1963), pp. ix, 74-5. The ORS was divided into four sections, focusing on ASW, anti-shipping operations, planned flying and planned maintenance and weather and navigation.
} 
These two organizations worked with a variety of others, both within and outside of Coastal Command, to contribute to learning and development.

They were able to collate both qualitative and quantitative evidence from operations and adapt techniques, weaponry and equipment based on them. A more comprehensive system was implemented in spring 1941 where, after an attack on a U-boat, aircrews would be debriefed back at their station by an intelligence officer and fill out a basic questionnaire detailing the attack. These would be forwarded to Coastal Command headquarters, where the decision would be made whether to not to call the crew in for further questioning to complete any gaps in knowledge. This process was useful not only for trying assess if there was a sinking, but also to improve ASW technique, to which it greatly contributed. A similar methodology soon followed for anti-shipping operations. ${ }^{24}$

Some key deductions that were made included the decision that summer to alter depth charge spacings and settings. Despite the weapon's adoption, the increase in sinkings up to spring 1941 had been limited. Voluminous ORS examination of operational reports revealed that U-boats attacked on the surface or within 15 seconds of submerging were vastly more likely to be damaged or sunk than those underwater for longer. They also found there was no unified attack procedure for using depth charges - the tactics used varied notably between squadrons and sometimes within them. Based on this evidence, a centrally administered tactical instruction was circulated to all units dictating that attacks should only be made on targets submerged for less than 30 seconds, and set out the first standardized attack procedure, including a dropping height of below 100 feet, new depth settings of 50 feet and 60 foot spacings between each charge. ${ }^{25} \mathrm{~A}$ year later, it was found that despite improvements to the

\footnotetext{
24 JSCSC, Coastal Command Review, No. 4, (July-August 1942), pp. 10-11; Coastal Command Review, no. 8, December 1942, p. 38. A later example of the questionnaire, adapted for use in the Mediterranean, can be found in BLSC, Kendrew Papers, NCUACS 11.4.89/B.36, 'M.E. Version of U-Bat', 22 June 1943. A simpler debriefings process had been used during the Battle of the Atlantic in the First World War.

${ }^{5}$ AHB, The RAF and Maritime War, Vol. 3: The Atlantic and Home Waters: The Preparative Phase, July 1941 February 1943, pp. 40-2; Bodleian Library Special Collections (BLSC), Kendrew Papers, NCUACS 11.4.89/B.38, Coastal Command Tactical Instruction No.15, 'Instruction for the attack of U-Boats caught on or near the surface', 25 July 1941.
} 
depth charge, there hadn't been a notable increase in successes as attacks frequently missed their target. The ORS came up with revised technique by cross referencing analys es of around 300 attacks with statistics on average bombing errors, lethality ranges and alternative stick spacings. They decided on 100 feet spacings as the optimum, setting it out in a new instruction, with an accompanying memorandum giving the explanation. It was one of several factors that brought improved results. ${ }^{26}$

Another success for this process was the development of 'Planned Flying and Planned Maintenance'. After a query from Churchill in early 1942 about serviceability rates, Coastal Command undertook investigations into the reasons for the low rate of sorties per aircraft available. The ORS submitted a report in June 1942 noting that the problem was not one of pilot endurance or restrictions on type of sortie, but one of maintenance. It recommended an increase and reorganisation of maintenance personnel in order to gain a large monthly increase in flying hours per aircraft. Aircraft maintenance schedules would be linked directly to the number of sorties they would be expected to fly, and squadrons ordered to ignore the serviceability target rate. Initial experiments on a handful of squadrons showed promise, as while serviceability rates dropped, the actual number of monthly flying hours achieved approximately doubled. The procedure was adopted in Autumn 1942, spread gradually throughout all Coastal Command and later across the whole RAF. ${ }^{27}$ The result greatly improved the efficiency of aircraft usage, which was of particular importance to Coastal Command, given its constant struggle for resources.

Other dissemination methods were also put in place to further improve the learning process, including the creation of Coastal Command Review in March 1942. This regular publication was distributed throughout the stations, groups and squadrons that served simultaneously to update everyone within the Command on its activities but also to further disseminate the

\footnotetext{
${ }^{26}$ AHB, The RAF and Maritime War, Vol. 4: The Atlantic and Home Waters: The Offensive Phase, February 1943 May 1944, p. 89.

${ }_{27}$ M. Kirby, Operational Research in War and Peace: The British Experience from the 1930s to 1970 (London, 2003 ), pp. 107-9; AHB, The RAF and Maritime War, Vol. 3, pp. 17-8.
} 
products of the learning process, es pecially to those below officer rank. Articles ranged from those outlining organisational procedures such as 'planned flying and planned maintenance' and the process of reporting attacks on U-boats and ships, to disseminating newly developed tactical procedures and the use of new technologies. These were designed to work in conjunction with the dissemination and justification processes of tactical instructions and memoranda, ensuring wider dissemination amongst aircrews who might not have received the information elsewhere. Often they would be presented in a more informal style and accompanied by entertaining cartoons, but there were also examples of reports and memoranda simply being reproduced. ${ }^{28}$ Phillip Joubert de la Ferte, under whose reign the Review was instituted, called it 'an imaginative and highly valuable monthly document'. His successor, John Slessor, remembered it as an important medium for 'making generally known the tactical lessons that were constantly being learnt in the course of operations' ${ }^{29}$

The mixed-methodology learning process that had evolved was certainly not always foolproof, nor did it represent a linear path of constant improvement. New challenges frequently arose and mistakes were inevitably made. Sometimes these would be a direct error from one of the organisations that formed part of the process themselves. While the ORS was pivotal in developing improved techniques and procedures, as well as the adoption of new technologies, there were times when they got it wrong. One clear example of this is their suggestion in late 1942 that the bomb was the most effective anti-shipping weapon, some way ahead of the torpedo. This was accepted by Joubert, who agreed that new anti-shipping tactics should be developed, with bombing as the primary method. It was only after a separate sub-organisation managed to prove that the research undertaken was done at time when the torpedo was being

\footnotetext{
28 See for example JSCSC, Coastal Command Review, No. 1, Jan-Feb 1942, p. 34; Coastal Command Review, No. 4, July-August 1942, p. 10; Coastal Command Review, No. 12, April 1943, p. 2; Coastal Command Review, Vol. 3, No. 7, July 1944, pp. 16-7. There were even some examples of it being used as an interactive learning forum, with questions (such as how best to assess the effect of a depth charge attack) being sent in by aircrew and answered by the staff ('The camera should be regarded as the pilot's friend'), see Coastal Command Review, no. 7, November 1942, p. 11.

29 P. Joubert De La Ferte, Birds and Fishes: The Story of Coastal Command (London, 1960), p. 169; J. Slessor, The Central Blue: Recollections and Reflections (London, 1956), p. 471. Alongside dissemination, the Review also acted to give aircrews a sense of what they were achieving, and so boost morale.
} 
handled in an ineffective manner that the idea was debunked. The changes were quickly scrapped. ${ }^{30}$

Periodically, flaws would also be discovered in the dissemination process. The circulation of reports among units and subsequent recommendations did not always reach all the required practitioners. As one Group commander complained in 1942;

'I find it very difficult to put my hand quickly on any record of our air operations or any analyses of these operations, with the lessons learnt. Any such record as there is seems to be handed on by word of mouth in conformity with the good old bardic tradition. The result is that exaggerated accounts get about of every operation and even the simplest of air operations becomes, in time, wrapped round with as much fantasy as a Norse saga.'31

To address the problem of gaps in this system, a meeting was held by the Vice Chief of the Naval Staff on 8 June 1942 to discuss the joint pooling of tactical, operational and training knowledge and facilities between RAF and RN. A process was put in place to ensure all Fleet Air Arm (FAA) reports along with attached comments would be forwarded by the Director of the Naval Air Division to the Deputy Director of Air Tactics at the Air Ministry and to Coastal Command Headquarters. The reverse process would be followed for Coastal Command reports, in a striking and quite rare example of inter-service co-operation. ${ }^{32}$

Despite some setbacks, a progressive intra-theatre learning process had been instituted at Home and it became increasingly linked with that in the Mediterranean, forming a cyclical intertheatre learning relationship that allowed for important developments in each.

\section{III: The Mediterranean Theatre and the Birth of Inter-Theatre Learning}

\footnotetext{
${ }^{30}$ AHB, The RAF and Maritime War, Vol. 3, pp. 409-10.

31 TNA AIR 15/631, Minute from AOC 16 Group to SASO, 5 February 1942.

32 The minutes of this meeting are quoted directly in TNA ADM 199/109, A 0876/42, Minute by DNAD, 9 July 1942.
} 
Over time, the initially resource-starved Mediterranean developed its own intra-theatre learning process which, like that for Coastal Command, used a mixed methodology incorporating non-formal methods and more organized formalized learning and dissemination processes. It initially acted purely as a receiver for knowledge transfer from the Home theatre, which at first came in the form of experienced aircrews and commanders, in order to develop new tactics, techniques and procedures. Later, the development of a more sophisticated Mediterranean intra-theatre process allowed wider cross-fertilization through numerous different means. The inter-theatre relationship morphed into a two-way, cyclical process that was mutually beneficial, from small-scale adaptations to a larger innovation in the form of the strike wings.

The opening of this theatre in June 1940, the addition of a new enemy and the pending French armistice all exacerbated Britain's problem of serious military overstretch, which would greatly hamper coastal operations there. Unlike at home, where the RAF had functional commands, RAF Middle East was a single, multi-functional entity. Its aircraft thus had to deliver all forms of operation across North and East Africa, the Middle East, Greece and the Balkans, the Red Sea and the eastern basin of the Mediterranean. There was no dedicated maritime organisation and a very limited overall total of aircraft; just six bomber, three fighter, two flying boat and one general reconnaissance squadrons. An additional squadron of obsolete flying boats at Gibraltar offered some coverage of the western basin. ${ }^{33}$

Britain's greatest priority in the summer of 1940 was defending the homeland from air attack and possible invasion. Therefore, despite multiple requests for more aircraft, the build-up in the Mediterranean theatre was at first very gradual. Furthermore, clear instructions from the Air Ministry dictated that the defence of Egypt and the Suez Canal took precedence above all other

\footnotetext{
33 Royal Air Force Museum (RAFM), Longmore Papers, DC74/102/38, 'Appendix 'B', 'Location of Units of Middle East Command as at 11 June 1940'; on the arrival of the firstaircraft at Malta, see K. Poolman, Night Strike from Malta: 830 Squadron RN and Rommel's Convoys (London, 1980), pp. 22, 27; Playfair et al, Mediterranean and Middle East, I, p. 120.
} 
operations, focusing the RAF initially on the threat from Italian forces in Libya. ${ }^{34}$ Under the circumstances, very few aircraft were allotted to maritime roles over 1940 and early 1941, and there was a particular dearth of modern types.

With such limitations, learning and development over this period had to take place in haphazard, ad hoc fashion, at a time when Coastal Command's methods were becoming more sophisticated. Initial developments in procedure were made by individual unit commanders. On Malta, basic rules for future shipping strikes and ASW were formed. Methods for the use of the shore-based FAA squadron in a bombing role were devised and the decision was taken that Sunderland flying boats were to be used only for reconnaissance, as they were currently too few and too valuable to risk on shipping strikes or ASW. The newly formed FAA squadron was to devote a significant proportion of its time to training, as 'Personnel...are not yet trained in torpedo dropping, so that although the frequent passage of large convoys is well known no attempt at interception and attack has yet been possible. ${ }^{\prime 35}$ The initial approach to training was that units would dedicate a part of their time to it, as the theatre lacked its own infrastructure. The subsequent creation of a torpedo training unit at Shallufa in Egypt was one of the first theatre-wide approaches to dealing with the early problems highlighted in coastal air power. It was later expanded into a full operational training unit for all coastal purposes. The training instructors there were not solely from the theatre itself, but also frequently from experienced Coastal Command aircrews who were reaching the end of their tour of duty, and so could pass on expertise. ${ }^{36}$

\footnotetext{
${ }^{34}$ On the precedence of the Home theatre for aircraft, see for example Christchurch Library, Oxford (CC), Portal Papers, Folder 12, Longmore to Portal, 14 October 1940, p.4 with Portal's attached comments, and Playfair et al, Mediterranean and Middle East, I, p. 61; on the primacy of Egypt and the Suez Canal, see RAFM, Longmore Papers, DC74/102/38, 'Appendix 'A', 'Air Council Instructions as to Responsibilities of Air Officer Commanding-in-Chief, Middle East', 11 June 1940.

35 TNA AIR 23/5697, Minute by SASO, 12 December 1940; HQ RAF Med to 228 Sq, 17 Dec 1940 ; 'Passage of Convoys to North Africa', 29 Dec 1940, pp.1-2.

${ }^{36}$ Air Publication 3233, Flying Training, Volume 1, p. 137; Nesbit, Armed Rovers, pp. 18-19; Goulter, Forgotten Offensive, pp. 168-9.
} 
In January 1941, a conference was held between the senior RAF and FAA officers on Malta to discuss shipping strikes, in order to improve methods and set down a standardized doctrine. By discussing experiences and examining reports, they were able to make several alterations to agreed operating procedures. At that stage, only the short-range FAA aircraft were capable of attacking vessels at sea on dark nights, and so it was determined that continued shadowing of enemy convoys by Sunderlands when targets were out of FAA range or no strike force was available was a wasted effort. Instead a new procedure was codified whereby sighting reports were to be made, after which the Sunderland would return to base. Hopefully, the enemy would be unaware that they had been located and a new attempt at location and then strikes by 830 squadron could be made at first light. A new doctrine was set in place to simplify the reporting procedure for sightings and set the procedure for dropping flares by Sunderland to illuminate targets at night for attack. Shortly after this, the command situation was further simplified, with the decision that the co-ordination and direction of all air efforts were to be made from the island's RAF headquarters. ${ }^{37}$

Yet this learning and development on Malta was very much localized and does not appear to have been shared directly with the headquarters in Egypt. Only the involvement of the new training organization offered a more comprehensive intra-theatre approach. One reason for this absence of a holistic approach was simply the lack of resources and limited use of coastal air power. This was to change in 1941 with the passing of serious invasion fears in Britain and an increased focus on the war in the Mediterranean and North Africa. The shift bought the beginnings of an inter-theatre learning process with it.

Over spring, pressure mounted from Whitehall on theatre commanders to do more to cut Axis communications between Italy and North Africa. ${ }^{38}$ In response to calls for increased mass in order to achieve this, and in a direct example of inter-theatre learning, the Chief of the Air Staff,

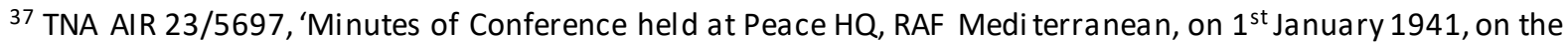
Subject of Interception and Attack of Enemy Convoys'; Air Operation Instructions, 10 January 1941.

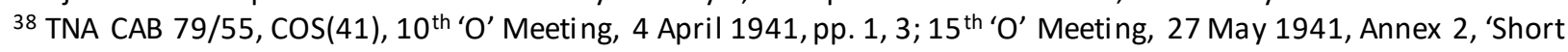
Appreciation on the Situation in the Middle East as I see it' by J G Dill.
} 
Charles Portal, decided that not only would new aircraft be sent overseas, but there would also be explicit transfer of knowledge and experience. Additional Blenheims were sent to Malta from No. 2 Group of Bomber Command, which had been engaged in anti-shipping attacks in the North Sea while seconded to Coastal Command, and had pioneered a new technique for lowlevel bombing at sea. What was more, they were accompanied by the Group's Senior Air Staff Officer (SASO) Hugh Lloyd, a key figure in driving this tactical development, who would take over as Air Vice-Marshal, Malta. In Portal's words, 'They will be able to take action against shipping with the special technique developed by that group', exporting it from the Home theatre to the Mediterranean. ${ }^{39}$

The technique, slightly adapted by Lloyd to fit the different conditions of the Mediterranean, involved Blenheims approaching the target at a height of only 50-100 feet and passing just over the ship's mast to drop their bomb loads in quick succession. This would often result in bombs penetrating the ship before exploding, causing it to catch fire. ${ }^{40}$ It was far more accurate than any other form of direct bombing at sea then in use, but the precision required meant operations had to take place in daytime. Operational research in the Home theatre found the technique bought increased rates of success but also very heavy losses, leading to their cessation in December $1941 .{ }^{41}$ The Mediterranean experience was similar, especially after Axis efforts to increase the level of anti-air armament on vessels that summer. Mounting casualties led Lloyd to telegram his AOC-in-C (Arthur Tedder) in August that the daylight attacks were 'sheer murder' for the aircrews, and they were later withdrawn from the role. ${ }^{42}$ Interestingly, while the parallel use of this technique was a product of inter-theatre learning, their near simultaneous abandonment appears not to have been, showing the inconsistent nature of links at this early stage.

\footnotetext{
${ }^{39}$ CC, Portal Papers, Folder 2, File 1, Portal to Churchill, 24 April 1941; Austin, Malta, p. 119.

40 H. Lloyd, Briefed to Attack: Malta's Part in African Victory (London, 1949), p. 45.

${ }^{41}$ Goulter, Forgotten Offensive, pp. 146-7, 154.

42 CC, Portal Papers, Folder 12, AOC Malta to HQ RAF ME, 18 August 1941; AHB, RAF and Maritime War, Vol. 6, pp. 266-7, 348-9.
} 
From mid-1941 the Mediterranean saw an increasingly systematized intra-theatre learning process, and an increasingly linked inter-theatre process with Coastal Command. New aircraft and technologies migrated from the Home theatre, and much sought after ASV sets began to arrive in increasing numbers. This raised another issue, however, in that RAF Middle East had relatively few aircrews trained in its use. ${ }^{43}$ In order to be able to make use of the increased allocation of sets, an experienced scientist from ORS Coastal Command was sent to assist with training and tactical development in its use. John Kendrew, a young talent who was to win a Nobel Prize in 1962, was the first operational scientist to arrive in theatre in October. He became the leading figure in coastal elements of RAF Middle East's own ORS, which officially became operational in early $1942 .{ }^{44}$

The Middle East ORS grew consistently over 1942-43, and was to come a significant driver in the adoption of new tactics and technologies in coastal operations. Over 50 reports were produced along with numerous memoranda and other analyses. The recommendations for the use of ASV and homing beacons became so useful that Kendrew decided to produce a 'Bible' for pilots, operators and controllers, bringing together all the latest details and recommendations in one place. ${ }^{45}$ It was circulated widely in-theatre, throughout staffs at RAF Middle East headquarters, Mediterranean Fleet headquarters, Malta, and to relevant RAF and FAA squadrons. It proved extremely successful; Tedder's SASO informed him that the improved and standardized techniques '...should enable both operations controllers and aircrews to get the very best out of their ASV equipment.' ${ }^{46}$ Given its success, Kendrew forwarded copies to the

\footnotetext{
43 R.S. Ehlers Jr, Mediterranean Air War, p. 228.

${ }^{44}$ Air Ministry, Operational Research, p. 109; BLSC, Kendrew Papers, NCUACS 11.4.89/B.2, Kendrew to Watt, 22 January 1942. Kendrew's work focused overwhelmingly on anti-shipping operations and ASW, and the associated use of ASV.

45 BLSC, Kendrew Papers, NCUACS 11.4.89/B.2, Kendrew to Parry, 12 May 1942, p. 2. The first and later updated versions of this 'bible' is held in BLSC, Kendrew Papers, NCUACS 11.4.89/B.35, Middle East Operational Research Section Report No. R.17: The Operati onal Employment of ASV (A Handbook for Aircrews and Controllers), 1 July 1942; Middle East Operational Research Section Report No. R.50: The Operational Employment of ASV (A Handbook for Aircrews and Controllers), 1 August 1943.

${ }^{46}$ BLSC, Kendrew Papers, NCUACS 11.4.89/B.2, Kendrew to Duckworth, 23 August 1942; SASO to Tedder, 9 July 1942.
} 
Home theatre, where Coastal Command's ORS disseminated it widely, and the RAF's Director of Technical Training incorporated much of its contents into training schemes for ASV. ${ }^{47}$

While transferring experienced commanders and personnel to the Mediterranean represented one ad-hoc method for inter-theatre learning, it was infrequent, with consequently limited impact. There were similar problems with the process for sending operational reports and other memoranda back and forth. They were often, but not always sent, and those that were frequently saw quite constricted circulation. In one example, after viewing multiple action reports from 830 Squadron FAA, members of the Naval Staff agreed several aspects of best practice for torpedo attacks on ships. Namely, they concluded that all moderate and large ships usually took more than one torpedo to sink, and it was better to attack an already-hit ship a second time for certainty than to attack another undamaged one. Agreement was also reached on the best area of a ship's hull to aim for. ${ }^{48}$ These decisions were passed on to the naval torpedo training school at Portsmouth, where they were incorporated into the programme. ${ }^{49}$ However, these reports and recommendations were not shared widely with relevant RAF authorities for some time, and it was recognized that oversights like this were a barrier to crossorganisational learning.

Following the meeting held by the Vice Chief of the Naval Staff on 8 June 1942 to discuss the joint pooling of tactical, operational and training knowledge in the Home theatre, a systemized inter-theatre process was also put into place. All FAA unit reports from the Mediterranean, together with attached comments from the Admiralty, were to be forwarded to the Air Ministry and Coastal Command. A reverse process would ensure reports and memoranda from units in Coastal Command would reach RAF Middle East, who would then disseminate them throughout their theatre. ${ }^{50}$ Thanks to this the circulation of reports between theatres was comprehensive, and it quickly led to adaptations in each.

\footnotetext{
47 BLSC, Kendrew Papers, NCUACS 11.4.89/B.2, Kendrew to Watt, 16 July 1942; Kendrew to Lugg, 3 August 1942; BLSC, Kendrew Papers, NCUACS 11.4.89/B.3, Lugg to Kendrew, 8 August 1942.

48 TNA ADM 199/108, Minutes by DNAD, DTSC, and DNC, 13 November 1941-13 January 1942.

49 TNA ADM 199/108, Minute by DTSD, 16 October 1942.

50 The minutes of this meeting are quoted in TNA ADM 199/109, A 0876/42, Minute by DNAD, 9 July 1942.
} 
Over mid-late 1942, there was a significant increase in the number of tactical memoranda and reports from shipping strikes in the Mediterranean theatre read by senior Coastal Command officers. These documents detailed tactical developments, often based on operational research, including best practices in height of approach to achieve surprise, aircraft formations, flaredropping techniques for night attacks, use of location and homing aids and the use of 'flak suppression' escort aircraft. ${ }^{51}$ These, along with prior experience and the examination of US and Japanese methods, formed the basis for a new innovation by Coastal Command in late 1942 - the Strike Wings. Using newly developed tactics that combined larger quantities of torpedo bombers with escorting aircraft specifically assigned for flak suppression, these dedicated shipping strike forces were the single biggest contributor in results for Coastal Command's five-year anti-shipping campaign and suffered proportionally lower casualty rates than previously used methods. ${ }^{52}$ As one important Coastal Command Tactical Memorandum noted, it was '...based on experience gained in anti-shipping work both in this Command and in the Mediterranean.'53 The development was such a success that when one Australian Coastal Command officer transferred to the South West Pacific area, he implemented some elements there in the ongoing effort against Japanese sea communications, including during the highly successful Battle of the Bismarck Sea. ${ }^{54}$

While Strike Wings were the most significant development derived from this formalised intertheatre process, smaller adaptations continued for the rest of the war. Knowledge transfer from Coastal Command directly influenced the incorporation of rocket projectiles into anti-

\footnotetext{
51 See for instanceTNA AIR 15/628, Discussion of ORS(ME) Report No. 4 held at RAF North Coates, 24 July 1942 ; TNA AIR 15/629, Report of Operations carried out by 828 and 830 Naval Air Squadrons, 25 May 1942; TNA AIR 20/1057, ORS(ME) Report R. 20, 'An Account of Anti-Submarineand Anti-Shipping Operations in the Eastern Mediterranean during May 1942', 14 July 1942; TNA AIR 23/1282, 'Air Tactics and Operational Notes on 201 Group Naval HQ RAF/M East Co-op Group by Tactics Assessment Officer', undated.

52 In addition to the reports in the previous footnote, see Goulter, Forgotten Offensive, pp. 180-4 on the sources of Strike Wing methods. For a summary of the results of Strike Wing operations, see Nesbit, Strike Wings, pp. $246-53$. 53 BLSC, Kendrew Papers, NCUACS 11.4.89/B.39, CCTM 59, The Employment of a Torpedo Force by Night', 12 April 1943, p. 1.

${ }^{54}$ G. P. Gilbert, The Battle of the Bismarck Sea, March 1943 (Australian Air Power Development Centre/Office of Air Force History, 2013), pp. 29-30.
} 
shipping operations in the Mediterranean in late 1943. Home theatre research had demonstrated that the $25 \mathrm{lb}$ warhead was much more appropriate than the 50lb for attacking small tonnage, low-draught targets. As these represented the vast majority of remaining targets in the Mediterranean at that stage, it was adopted there as standard. ${ }^{55}$ There were similar inter-theatre influenced adaptations in ASW. After comprehensive research from Coastal Command found that the smaller the target, the lower the optimum height was for the use of ASV, the operating procedure for anti-submarine operations in the Mediterranean was revised accordingly. Procedures for the use of delayed-action flares and the adoption of the Leigh Light were also based on or altered because of knowledge transferred from the Home theatre. ${ }^{56}$

That is not to say this system was flawless or always fully appreciated. On receiving reports in November 1942 showing some recent poor performances by torpedo bombers in the Mediterranean, Joubert de la Ferte exclaimed 'I realise that the statistics prove nothing, but on form it does not look as though we have a lot to learn from the Middle East.' This bought a sharp rebuke from Portal, who strongly advocated doing so. ${ }^{57}$ While the formalised process allowed greater proliferation in the transfer of knowledge between theatres, it also did not end the ad-hoc approach entirely. Unit commanders, training officers and aircrew continued to transfer knowledge on a non-formal or semi-formal basis as they were transferred between or visited theatres. Some adaptations continued to come from these methods. A good example is the visit by Wing Commander Cliff, of Coastal Command's Air Tactics division, to Malta and Egypt in December 1942. Based on his observations and discussions, he bought back recommendations on adaptations to be made in the use of longer-burning flares for all types of night operation, changes to training for torpedo operations, methods to use Beaufort and Beaufighter aircraft in combination and ways to modify Wellington aircraft to increase their

\footnotetext{
55 TNA AIR 23/7189, Northwest African Coastal Air Force-Anti-Shipping Weapons, 8 December 1943; TNA AIR TNA AIR 23/7543, HQ RAF ME to AHQ Eastern Mediterranean, 3 April 1944.

56 TNA AIR 20/1057, ORS(ME) Report R. 28, 'An Account of Anti-Submarine Operations in the Eastern Mediterranean, July-December 1942', 8 February 1943, p. 8; ORS(ME) Report R. 20, 'An Account of Anti-Submarine and Anti-Shipping Operations in the Eastern Mediterranean during May 1942', 14 July 1942, p. 3; TNA AIR 23/926, Notes on ASV Performance in the Middle East, 5 November 1942, pp. 1-2; AHB, The RAF and Maritime War, Vol. 7, Part 1, pp. 15, 49.

57 CC, Portal Papers, Folder 8, File 3, Joubert to Portal, 9 November 1942; Portal to Joubert, 10 November 1942.
} 
endurance. He also gave a lecture at the headquarters of RAF Middle East on the operational methods of Coastal Command and advised operational training unit staff on a modification to make to torpedoes fitted to Beaufort aircraft to improve their use at night. ${ }^{58} \mathrm{His}$ report was not shared as widely as those incorporated within the formalized process, only being circulated within Coastal Command itself.

This mixed methodology that had evolved in the Mediterranean was similar to that of Coastal Command and it accompanied the creation of a mutually beneficial relationship with the Home theatre, which spurred important developments in each. Relations were much more limited and directive when it came to the Indian Ocean, however.

\section{IV: The Indian Ocean and the Limits of Inter-Theatre Learning}

Given the vast commitments and finite resources over the course of the war, tough decisions regarding their allocation had to be made on a regular basis. As Henry Probert has demonstrated, the decisions consistently left those east of Suez under-nourished: 'First and quite simply the RAF in the Far East was - like the other Services - always at the back of the queue for everything. ${ }^{59}$ This proviso must be borne in mind when understanding the slow pace of both intra and inter-theatre learning regarding the Indian Ocean.

RAF Far East had just 158 aircraft of largely obsolescent types to resist the Japanese attack in December $1941 .{ }^{60}$ After the fall of Singapore the new theatre commander, Richard Peirse, informed Portal of the need to greater coastal air capability, as he recognized maritime operations as one of his three core roles. The Navy needed much better reconnaissance if it was to resist any invasion attempts against Ceylon or India, and a much increased air striking force would also be a boon in this regard. Shipping protection, particularly on the coast

\footnotetext{
58 TNA AIR 15/633, Report by Wing Commander Cliff on Visit to Middle East, 24 December 1942.

59 Probert, Forgotten Air Force, p. 301. Throughout the war RAF saw repeated changes in command structures and theatre boundaries east of Suez, but parts of the Indian Ocean were always viewed as being within the 'Far East', see D. Richards and H. St George Saunders, The Royal Air Force, 1939-1945, Vol. 2, pp. 5, 371.

60 TNA CAB 66/28/33, Despatch on the Far East by Air Chi ef Marshal Brooke-Popham, 8 September 1942, p. 31.
} 
between Ceylon and Calcutta, was evidently a vital duty. He suggested much more was needed in the way of resources, while command and control should be vested jointly between the services. As he emphasized to Portal, the RAF and Royal Navy were already working well together in the same headquarters in Ceylon. ${ }^{61}$

Not only were most calls for more aircraft in 1942 rejected, so were requests for experienced personnel. In March Portal refused an appeal from Peirse for someone of Air Vice Marshal rank '...to draw up plans for tactical handling and to ensure close co-ordination with naval policy', instead suggesting someone could be sent from RAF Middle East. ${ }^{62}$ Tedder was highly reluctant and ultimately nothing appeared beyond a mid-ranking maintenance officer, while Coastal Command later sent a Group Captain for a short tour. Tedder's proposed alternative was for personnel to transfer into his command to gain relevant knowledge and then return, but sheer lack of manpower in the Far East precluded this in the short term. ${ }^{63}$

The consistent neglect of the theatre led Admiral Somerville, C-in-C Eastern Fleet, to make direct requests when visiting the Home theatre at the end of the year. He expressed amazement at the progress of Coastal Command since his last visit, and suggested that in the Indian Ocean they were 'backwards' by comparison. For all the willingness of the RAF to cooperate, Somerville labelled them 'rather amateurs at this GR [coastal] game'. He called for the creation of an Indian Ocean Coastal Command and for Joubert de la Ferte to be sent to make a tour of inspections of the current set-up and dispense advice. ${ }^{64}$

The response was mixed. Portal ordered that the question of a dedicated Command be investigated, but ultimately the sheer size of the theatre defeated the prospect. ${ }^{65}$ The request

\footnotetext{
${ }^{61}$ RAFM, Peirse Papers, AC71/13/73, Peirse to Portal, 28 February 1942; CC, Portal Papers, Archive 2, Box C, Folder 4, Peirse to Portal, 24 May 1942, pp. 2-3.

62 RAFM, Peirse Papers, AC71/13/73, Peirse to Portal, 28 February 1942, p. 2; Peirse to Portal, 8 March 1942; Air Ministry to AOC-in-C India and AOC-in-C Middle East, 12 March 1942.

63 RAFM, Peirse Papers, AC71/13/74, Peirse to Portal, 18 March 1942; Tedder to Peirse, 16 March 1942; TNA AIR 20/3812, DONC to ACAS, 11 Dec 1942.

64 TNA AIR 20/3812, ACAS (P) to DONC, copied to DO Ops, 9 Dec 1942, pp. 1-2.

65 TNA AIR 20/3812, ACAS (P) to DDP (O), 9 Dec 1942.
} 
for high-level knowledge transfer via Joubert was categorically refused however. The Air Marshal had been earmarked to become the new Inspector General and Portal was adamant that he must remain in the UK to prepare for the role. Instead he expressed a need to ensure Coastal Command tactical memoranda were consistently sent out to the Indian Ocean. The RAF Director of Naval Co-operation confirmed that this was the case, while the number of Coastal Command Review copies sent to India and South Africa would be increased. Finally, a pair of Wing Commanders from Coastal Command were assigned to Durban to liaise with South African authorities on ASW, the quality of which had come in for sharp criticism from both Somerville and Peirse. ${ }^{66}$

The limited nature of the Air Ministry response bought expressions of great disappointment from the theatre commanders. Somerville emphasized the importance of a mixed methodology in facilitating successful inter-theatre learning, stating that 'Published reports of operational experience and tactics are of great value but cannot adequately take the place of personnel visits with the opportunities furnished thereby for discussion and criticism. ${ }^{\prime 67}$ Such appeals remained in vain however, and they had to make do with the limited resources, knowledge and experience at their disposal. Incremental increases in both numbers and modernity of aircraft allowed for some improvements in capability, yet the lack of means for tactical assessment through substantially sized development units and operational research meant that Coastal Command methods were often simply copied directly when new adaptations were communicated to the theatre. Little or no research was done in order to apply alterations and make them suitable for the unique conditions of the Indian Ocean, which on occasion proved damaging. One example of this is alteration in depth charge settings and spacings from those set out in tactical instructions sent to India and Ceylon. The charges were altered to a deeper setting based on limited experimentation by 222 Group and an unqualified assumption that clearer water than the Atlantic would benefit the change. The implemented changes, based on

\footnotetext{
66 TNA AIR 20/3812, ACAS (P) to CAS, 8 Dec 1942; CAS to ACAS (P), 9 Dec 1942; ACAS (P) to DDP (O), 9 Dec 1942; DONC to ACAS, 11 Dec 1942.

67 TNA AIR 20/3812, Somerville to Slessor, 21 December 1942.
} 
limited experimentation by inexperienced individuals, proved to be detrimental and bought sharp rebuke and prompt reversal. ${ }^{68}$

The development of an intra-theatre process was extremely slow, hampered by resource and expertise scarcity and the communication difficulties caused by the sheer size of the theatre. In a testament to this sluggish progress, Kendrew was forced to write a report into ASW operations in the Indian Ocean in 1943 entirely from Cairo, as there were no suitable personnel available in-theatre. He did so for want of any alternative, at a time when '...the UK is howling for information'.69 An ORS India was belatedly opened in February 1943, but the tiny organization focused entirely on radar issues related to the war in Burma. Only gradually, after an increase in experienced personnel that included the transfer of a rather reluctant Kendrew, did it incorporate coastal-related work and directly integrate a handful of scientists with 222 Group. $^{70}$

The gradual crystallization of an intra-theatre process was aided in late 1943 by a decision to alter the boundary between theatres alongside the concurrent creation of South East Asia Command. The Air Headquarters in East Africa, Aden and Iraq were linked operationally with the Indian Ocean rather than the Mediterranean, while remaining under the administrative ownership of RAF Middle East. Operational direction throughout the whole theatre would be vested in 222 Group at Ceylon, although each headquarters had a high degree of autonomy. ${ }^{71}$ This change ironed out problems of disjointed command between Ceylon, India and air assets based in East Africa and the Red Sea. The centralization of coastal operations in Ceylon largely eliminated the problems of tactical memoranda and operational reports from disparate units

\footnotetext{
68 TNA AIR 23/5291, Air Ministry to all overseas Commands, 19 January 1943; Bunce (Air Tactics) to SASO 225 Group, with attached draft letter, 18 September 1943; Summary of Correspondence between AHQ India, AHQ Bengal HQ 222 Group and HQ 225 Group concerning depths setting and tactical instructions, Sq Ldr (Air Tactics), 3 November 1943.

69 BLSC, Kendrew Papers, NCUACS 11.4.89/B.4, Kendrew to Bryer, 18 March 1943.

70 Air Publication, Operational Research, pp. 125-6, 168, 172.

71 TNA AIR 20/3834, COS(43) 312, 'Command of Aircraft Allocated for the Protection of Sea Communications in the Indian Ocean Area', 10 December 1943.
} 
and sub-commands not reaching the correct authorities for examination, which was a problem that Kendrew had immediately noticed on arrival. ${ }^{72}$

An increasingly formalized process was then instituted to ensure the collection of data from reports and conduct research via the small ORS. Procedures were laid down to ensure previously sparse reports would offer much more substantial information. Finally, a systematized exchange of lower and mid-level officers with other theatres was belatedly organized. ${ }^{73}$ The measures took time to take effect and numerous other problems remained. By February 1944, for instance, complaints were still being made that the information in operational reports was too thin, and while they now all reached Ceylon, they still went via Dehli in a highly inefficient process. ${ }^{74}$ More problematic was the continuing dearth of experienced officers at higher levels of command coming from other theatres.

The situation, at a time when U-boat activity in the Indian Ocean was increasing, prompted Louis Mountbatten, the Supreme Commander South East Asia, to make an acerbic appeal to Portal; 'Do you think the time has come when you can spare a few up to date experts from the Battle of the Atlantic to get the Battle of the Indian Ocean started?' ${ }^{75}$ This time Portal's response was swift; answering that he was already implementing such a transfer. Albert Durston, Slessor's SASO at Coastal Command, was earmarked to facilitate such knowledge exchange by becoming the new commander of 222 Group. ${ }^{76}$ Durston was an extremely experienced and accomplished operator, whom Slessor had referred to as his 'right hand man' and an 'old salt' ${ }^{77}$ He became the new 222 Group commander that spring and immediately set to work bringing about change.

\footnotetext{
72 BLSC, Kendrew Papers, NCUACS 11.4.89/B.7, Kendrew to Minnis, 27 January 1944. Prior to this change, India had retained separate control of some coastal operations over Ceylon.

73 TNA AIR 20/3834, HQ SEAAC to Air Ministry, 14 December 1943; HQ SEAAC to Air Ministry, 25 December 1943.

74 BLSC, Kendrew Papers, NCUACS 11.4.89/B.3, Miller to Kendrew, 3 February 1944.

75 CC, Portal Papers, Folder 12, Mountbatten to Portal, 3 January 1944.

76 CC, Portal Papers, Folder 12, Portal to Mountbatten, 24 January 1944.

77 Slessor, The Central Blue, p. 485.
} 
One of his first acts was to create the 'Indian Ocean General Reconnaissance Operations' staff (dubbed 'IOGROPS') as a separate organization, subordinate to 222 Group. This staff would travel around the heterogeneous headquarters scattered across the vast theatre in order to standardize the organization, tactics, techniques and procedures used in coastal operations. ${ }^{78}$ It allowed Durston to implement adaptations consistently and far more quickly across the theatre. Many of them simply brought the units up to date with long-standing practices of Coastal Command. When Kendrew discussed the idea of implementing planed flying in IOGROPS with Durston, he found 'He is most anxious to go ahead' and have one ORS man permanently dedicated to that job. ${ }^{79}$ The belated imposition of this method throughout the Indian Ocean vastly improved the efficiency of escort by coastal air power. ${ }^{80}$ Prior to that, it was estimated that in May 1944 alone, aircraft from East Africa and 225 Group had wasted over half their flying hours by escorting low-risk convoys. ${ }^{81}$

Durston also ensured that multiple methods of dissemination were used. The various Indian Ocean tactical instructions and memoranda were gathered into a single book. Copies were then distributed to all squadrons with instructions that ea ch aircraft should carry one, as they would often be called on for a variety of complex tasks. While this was a highly directive top-down method, he did allow that 'The tactical instructions should be adhered to unless some special incident occurs that necessitates an alteration being made. The reasons...must be fully justified however. ${ }^{82}$ Alongside this, IOGROPS Quarterly Review was created. Acting as an equivalent of Coastal Command Review, it furthered dissemination in a slightly more entertaining style, and was specifically aimed at reaching all aircrew, as well as officers. ${ }^{83}$

\footnotetext{
78 AHB, The RAF and Maritime War, vol. 7, part 3, p. 158; Banks, Wings of the Dawning, pp. 287-8.

79 BLSC, Kendrew Papers, NCUACS 11.4.89/B.10, Kendrew to Capon, 3 June 1944.

${ }^{80}$ RAFM, Peirse Papers, AC 71/13/80, Somerville to Peirse, 3 August 1944.

81 Probert, Forgotten Air Force, p. 197.

82 TNA AIR 23/4803, 'Indian Ocean General Reconnaissance Operations Tactical Instructions and Memoranda', Introduction page, undated. Many of these were essentially copies of those from Coastal Command.

83 TNA AIR 23/1953, IOGROPS Quarterly Review, Vol. 1, No. 1 (July 1944), front matter.
} 
IOGROPS continued to expand and progress over 1944, aided by the acquisition of several experienced Coastal Command ORS members in the first quarter of the year. They were able to start making their own theatre-specific assessments of ASV requirements and re-write tactical instructions, rather than simply mimicking those of Coastal Command. ${ }^{84}$ Although the level of output was dwarfed by that of the other theatres, they did make some useful progress in increasing efficiency in the use of ASV to locate convoys for escort and in the siting of landbased beacons. ${ }^{85}$

Thus from mid-1944 onwards, the Indian Ocean belatedly developed a noteworthy intratheatre learning process, while also acting as a recipient of knowledge transferred from elsewhere. They were able to make modest developments and adjustments based on the unique conditions and requirements of the theatre, either through the ORS or an increased tactical development unit. The efficiency and speed of change was increased tha nks to changes in organization and dissemination methods, pioneered under Durston in particular. They also became far more capable at keeping abreast of developments elsewhere thanks to improved inter-theatre links. Technical information was requested on occasion to help incorporate new equipment such as rocket projectiles, while the rotation of personnel across theatres was regularly encouraged to ensure the latest practices were being adhered to. ${ }^{86}$

These developments came very late, however, with some fairly basic principles such as prioritizing convoys for escort not being instituted until summer 1944, not long before significant danger to sea communications started to recede, and so the achievements of coastal air power were much more limited than elsewhere. While the intra-theatre process was greatly

\footnotetext{
84 BLSC, Kendrew Papers, NCUACS 11.4.89/B.42, Operational Research Section, South East Asia Command, Progress Report no. 5, April-June 1944, p. 1.

85 BLSC, Kendrew Papers, NCUACS 11.4.89/B.44, ORS 222 Group (IOGROPS), 'The Performance of ASV beacons in India and Ceylon, 20 July 1944; ORS 222 Group (IOGROPS), 'Perimeter Patrols by Single Aircraft on Convoy Escort', 26 September 1944.

86 BLSC, Kendrew Papers, NCUACS 11.4.89/B.19, Menzies to Kendrew, 12 December 1944; Kendrew to Menzies, 25 December 1944; BLSC, Kendrew Papers, NCUACS 11.4.89/B.20, Kendrew to Roberts, 22 January 1945; TNA AIR 23/5010, Indian Ocean G.R. Tactical Instruction No. 36, 'Tactical Use of RP against U-boats', distributed 6 March 1944.
} 
improved, and the Indian Ocean became a receptor for knowledge transferred from the other theatres, it was never able to create anything of sufficient use to be sent back, in the manner that the Mediterranean theatre had.

\section{V: Conclusions}

Coastal air power was an essential element of Britain's survival, and later Allied victory, in the war. Yet Britain began with it mired in a dire state, lacking modern aircraft, equipment, specialist training techniques and starved of conceptual development. Learning and development was therefore central to success, in order to bring it up to a state capable of coping with the rigours of modern warfare, and to keep near the forefront of technological, organizational and tactical change driven by the nature of total war and by the actions of the enemy.

Coastal Command began by taking an ad-hoc approach to identifying problems with existing techniques and equipment, and to developing new tactics and solutions. This was often done in a limited way by frontline units, and ideas were disseminated in an inconsistent manner. From late 1940 onwards, an increasingly systematized process was put into place, involving increased specialized training, a dedicated development unit and an ORS, which worked together to develop new procedures, analyse operations and incorporate new technologies.

The integration of these organizations allowed a formalized process for both the gathering of information for assessment and the dissemination of new developments and instructions. The use of Coastal Command Review alongside direct top-down tactical instructions and memoranda helped ensure that new practices were adopted widely and adhered to effectively. This more formalized process bought greater inclusion and allowed for larger-scale change, but did not entirely replace the previous ad-hoc methods, which continued to run parallel to it and allowed for some useful localized, bottom-up adaptation. The combined methodologies bought 
a raft of important improvements in areas such as ASW, reconnaissance, escort and antishipping operations.

As the war became truly global, new issues were raised in the Mediterranean and Indian Ocean. With the Italian declaration of war coming at a particularly difficult time, the Mediterranean was initially left to 'fend for itself' conceptually, as well as receiving few resources.

Developments occurred slowly and on a small scale at first, and were rather disjointed between Malta and Egypt. The genesis of inter-theatre learning took place in 1941, with the transfer of experienced commanders, aircrews and later scientists, who were sent with the specified aim of transposing Coastal Command procedures and expertise directly onto the Mediterranean. While this initially took place, it was accompanied by the evolution of the Mediterranean's own intra-theatre infrastructure, which grew to incorporate dedicated coastal development and training units and a highly active ORS. The Mediterranean thus transformed from a pure receptor for knowledge transferred from the Home theatre, to also being an effective learning environment in its own right that allowed for independent production. Developments there were not only of intra-theatre use, but were often transferred back to Coastal Command, leading to small-scale adaptations and more substantial change, such as the creation of the highly successful Strike Wings. The result was a cyclical, mutually beneficial relationship, which had a significant and positive impact on the British war effort. The relationship became increasingly systematized from 1942 onwards, although without ending the previous ad-hoc methodology.

For the Indian Ocean, the story was far less positive. It was not only consistently starved of resources, but also of the mechanics for intra-theatre learning and knowledge transfer from elsewhere. Coastal air power remained in a sorry state over 1941-43, using outmoded aircraft, equipment and methods to limited effect. The belated transfer in 1944 of scientists and highlevel officers experienced in the organization of coastal air power finally allowed for substantial intra-theatre development, using an ORS, a tactical development unit and various dissemination techniques. This consisted almost exclusively of the overdue implementation of 
long-standing basic procedures from other theatres. New, theatre-specific developments, were few and far between. The Indian Ocean thus belatedly saw a competent intra-theatre organization for the dissemination of learning in 1944-45, whether received from another theatre or developed on location, although this was arguably too late to have any notable effect on the war. At no point was any Indian Ocean development deemed worthy of consideration for use in the other two theatres, and so it failed to benefit from a cyclical relationship like that of the Home and Mediterranean theatres.

Looking at the case study of coastal air power, the British had demonstrated, at least in this particular capability, that they were broadly able to integrate learning with the global nature of the war. Overall, learning and development in coastal air power, which was so crucial during the war, was conducted both intra and inter-theatre. Between the Home theatre and the Mediterranean, this grew into a dynamic, cyclical, mutually beneficial relationship that had a demonstrable positive impact on the war, but the Indian Ocean remained the poor relative, and could only act as a receptor to knowledge. Inter-theatre learning was thus an important element in the success of coastal air power, although it evidently had its limits. 